\title{
The Theory of Cultural Racism in Toni Morrison's Tar Baby
}

\author{
Hala Ewaidat \\ $\mathrm{PhD}$. Of English Literature and Culture \\ Department of Foreign Languages, Faculty of \\ Education, Mansoura University, Egypt \\ halaewaidat@mans.edu.eg
}

\section{Abstract}

For years scholars of literature and sociology have studied racism in Toni Morrison's works. Still, the theory of cultural racism and its impact on African -Americans in Morrison's Tar Baby requires further investigation, which is the goal of this paper. In this novel Morrison explores the theory of cultural racism through two main pillars of the theory: first, 'the superiority of the European culture' practiced by the whites against the blacks and by the blacks against their own race and the second is 'history' and the black heritage as a constituent element in the history of the American nation. The theory is defined and then traced through analyzing the central female character of the novel, Jadine, the African American victim of the practices of cultural racism that she herself inflicts on her black race. The conflict regarding her self-definition: birth, race, color, status, and education and her relationships with all the people who bring this conflict into play (relatives, foster parents, lovers, imagined women and real women) are investigated to understand the fact that the suffering of Black Americans continued to the present after the 
abolishing of racism because of cultural racism. In Tar Baby, Morrison wrangles with one of the great questions of contemporary American life: How can an individual (or a group) mediate both cultural distinctiveness and national cohesiveness in an increasingly diverse America? Evidently, Morrison has got her own objective, namely, AfricanAmerican people must not abandon their ethnic heritage if they want to reconcile their own culture with the dominant national culture.

Key Words:

African-American, heritage, racism, theory of cultural racism, white race superiority

\section{[1]Introduction}

In May 26, 2020, while the world was in a lockdown owing to the COVID-19 pandemic, George Floyd's cry, "I can't breathe" initiated a global uprising that started in the United States and spread to other European countries and Australia against racism, as documented in a New York Times article. Unlike similar murders, this killing in the 21st century is not simply the murder of an African-American whose only guilt is being black, Cecilia Barbieri and Martha $\mathrm{K}$. Ferede stated, it is "about the senseless killing of millions over many centuries, the unequal and unjust treatment, the different forms of violence, the economic and social inequality, the lack of opportunity, the racial profiling, the marginalization, the micro-aggressions and the countless 
daily indignities". Since the publication of her first novel, The Bluest Eye in 1970, Toni Morrison (1931-2019) dedicated her life to purge the American society from deep rooted racism and wrangled with cultural questions to raise awareness to social ills in contemporary American life that resulted from cultural racism. In 2019 Engel Valery Viktorovich remarked that, "modern racism is not about the race" but "about the culture". Jams Blaut asserts, "What counts is culture, not color". (Blaut 1992, 291). Back in1954 the American psychologist Dr. Gordon Allport, mentioned in Theory of Personality Traits, that cultural racism arises when "one group declares its claim to determine cultural values for the whole society."

Using the theory of cultural racism as the major point of reference, this study examines Toni Morrison's Tar Baby (1981), a novel that displays the mutual animosity and prejudices between blacks and whites in general and between blacks and their fellow blacks in particular. For years scholars of literature and sociology have studied racism in Morrison's works, still, the theory of cultural racism and its impact on the African -American culture in Morrison requires further investigation which is the goal of this paper. As a theory "Cultural racism. . needs to prove the superiority of Europeans without building on older arguments from religion and biology ... and to do this the theory has turned to 'history' to justify and construct "the characteristic theory of cultural (and intellectual) history".(Blaut, 1992. P.297) Instead of the biological superiority of the European race, the history of their culture is the substitute. In Tar Baby, Morrison explores the theory 
of cultural racism through two main pillars of the theory first, 'the superiority of the European culture' practiced by the whites against the blacks and by the blacks against their own race and the second is 'history' and the black heritage as a constituent element in the history of the American nation.

\section{[2]Cultural Racism as a Socially Dominant Construct}

The term 'racism' is one of the most contentious and intricate concepts in social sciences but Morrison abridged the complexities of the problem, she once wrote, "There is no such thing as race. "None. There is just a human race- scientifically, anthropologically. Racism is a construct . . . it has a social function, racism". According to Blaut, "Racism most fundamentally is practice: the practice of discrimination, at all levels, from personal abuse to colonial oppression" (289). He supports this claim further by mentioning that in a contemporary academic context, when describing a person as 'racist', "we are accusing this person of believing in the hereditary, biological superiority of people of one so-called race over people of another socalled race, with the implication that discrimination is justified, explained, rationalized, by the underlying biological theory". (290). Since the 1980s, there has been extensive debate -especially in Britain, France and the USabout the changing nature of an earlier, overt racism and a more recent, covert racism which focuses on issues of religion, culture, and ethnicity, "about the relationship between biological racism and prejudices rooted in cultural 
difference"as Rattansi explained the new construct 'cultural racism'. (95)

In the 1980s and 1990s, West European theorists like Pierre-André Taguieff, Martin

Barker, and Étienne Balibar substituted the term "racism" by the new theory of cultural racism. Among the scholars who defined this theory in 1991 was Balibar who emphasized that the essence of "cultural racism" is the belief that "some cultures are superior to others". He described it as having as its principal theme not biological heredity, "but the insurmountablility of cultural differences, a racism which, at first sight, does not postulate the superiority of certain groups or peoples in relation to others but 'only' the harmfulness of abolishing frontiers, the incompatibility of lifestyles and traditions"; nevertheless, when put into practice, "cultural racist ideas reveal that they inherently rely on a belief that some cultures are superior to others".

According to Blaut in his Theory of Cultural Racism, "Cultural superiority was mainly, though not entirely, considered to be an effect of racial superiority". (292) In 2020 in his introduction to 'Racism' in the Introduction to Oxford Bibliographies, Thomas F. Pettigrew noted that, "structural and cultural racism results when a society's institutions are shaped by racist beliefs and results in group discrimination". With struggles for independence and rejection of racism of the colonized and colored peoples in the post-colonial times, European countries started searching for an alternative for the 'classical racism' that would enable them to maintain their economic control over 
post-colonial regions. Now that equality among races is internationally recognized, the problem remained that 'nonEuropeans' . . . cannot develop economically to the level achieved by Europeans unless these societies voluntarily accept the continued domination of European countries and corporations; in other words, neocolonialism".

This iterates Chau's definition of Cultural racism in The Wiley-Blackwell Encyclopedia of Social Theory, as "the institutional domination and sense of racial-ethnic superiority of one social group over others, justified by and based on allusively constructed markers, instead of outdated biologically ascribed distinctions". The outcome of this truly massive theory- building effort was the theory of "modernization." This theory argued, in essence, that nonEuropeans are not racially, but rather culturally backward in comparison to Europeans because of their 'history': their lesser cultural evolution. . . . Non-Europeans were thereby defined as inferior in attained level of achievement, not potential for achievement. This was the real essence of cultural racism (Blaut, p. 294).

[3]Morison's Tar Baby through the Lens of the Theory of Cultural Racism

Margalit Fox in 2019 described Morrison's fourth novel, Tar Baby (1981)," as dealing "explicitly with issues of racial and class prejudice among black people". When reading the novel a critical eye can detect that what agitates and frustrates Morrison most in Tar Baby is the impact of 
the superiority of white culture on black people who adhere to its principles and practice prejudices toward other blacks. She discloses her own bitter and deep-rooted resentment at light-skinned blacks who assimilate white culture and values and turn them into a grudge against dark-skinned ones; light-skinned women treat dark-skinned men and women with haughty contempt. Anniina Jokinen notes, "Prejudices exist between the white and black people in the house; between the black people of the house; the black people and the local populace". Heinze noted that, "Such is the world Morrison creates in her novels in which people of the same race can be embroiled in a civil war as subtle as a reproving glance or blatant as a verbal assault" (21).

Morrison's Tar Baby, basically "chronicles the love affair of a cosmopolitan, European-educated black woman(Jadine) with a rough-and-tumble local man(Son)"as Margalit Fox asserts. Jadine, the daughter of Sydney's dead sister, an African-American light-skinned black woman, who is raised in the Caribbean island of Dominique by her surrogate black parents, Ondine and Sydney Childs, a butler and a maid for a retired white factory owner, Valerian Street and his wife Margaret. Ondine, Sydney and Jadine, Thérèse, Gideon, and Alme Estée, depend on the white Streets for their livelihood just as the white Streets depend on them for their service and loyalty. These black people, including Son, are not frightening characters, "except perhaps inasmuch as they represent the worst fears of white racists: that black people have aspirations and a sense of self beyond basic instincts of survival" as McKay explains (6). However, 
thanks to Valerian's and Ondine and Sydney Childs' assistance, Jadine has graduated from The Sorbonne as "an accomplished student of art history ... . an expert on cloisonné" (116). She lives a life which revolves around New York and Paris where she has become an art historian and a high fashion model. Heinze describes her as "the epitome of ideal white womanhood" (122). She is thinking seriously of marrying Ryk, a wealthy man from Paris. Son is a dark-skinned refugee who has worked as a sailor. He jumps ship in the Caribbean, lands on the Isle des Chevaliers, and ends up at the Streets' magnificent villa, L'Arbe de la Croix, searching for food and water. One night Margaret finds Son in her closet. Sydney brings him down and Valerian permitted him to stay in the guest room, much to the surprise, displeasure and suspicion of Margaret, Ondine and Sydney, and their niece, Jadine, who is coming from Paris to visit her guardians and benefactors. However, son manages to soothe everybody's anger. Unlike the occupants of L'Arbe de la Croix who depend entirely on Valerian for their living, Son is not threatened by Valerian, though he provides him with food and clothes. Still, Son feels no commitment since he does not depend on him for survival. Son's presence among the other members of the villa disturbs their lives by waking them up to the realities of who they are. It also embarrasses Ondine and Sydney, threatens Margaret sexually, and serves as a cultural reminder to Jadine. Yet, Son is, according to Heinze, a "living force" that "thumps plants back to life, brings love to Jadine, and renews Margaret's and Valerian's hope of regaining their estranged son". (127). Not having "seen a 
Black like him in ten years" (126), Jadine, however, is repelled at first, and then attracted by him. Son was able to make Jadine fall in love with him. Ultimately, after she yields to his advances, they make love and go to New York City. They live there as lovers. Months later, Son takes Jadine to his hometown Eloe, Florida, where she feels "bored and disrespectful" (Rayson). So they go back to New York where they often fight. After a particularly "violent struggle" (264), Jadine leaves the city to collect her belongings from the Streets` villa. Afterwards, she leaves for New York to seek her Parisian lover who wants to marry her. Son decides to pursue her but confronts some obstacles. Eventually, he ends up on Isle des Chevaliers where he is seen walking toward the trees. Perhaps his "only recourse is to run, like a rabbit, into oblivion and myth" (Rayson). It remains a mystery whether he joins the mythic horsemen on the Isle or tracks down Jadine.

Morrison's preoccupation with contentions and conflicts grounded on cultural racial prejudices figures clearly in her portrayal of Jadine, the central female character of Tar Baby. Morrison's depiction of Jadine can be considered as a fundamentally profound image of the concept of cultural racism. Affected by white 'superior culture' Jadine disdains her own black race. Believing in the 'the superiority of the European culture, adheres to the practices of the Whites against her own people. It is Morrison's fulfillment of Jadine, a Sorbonne-educated model that clarifies the idea of cultural racism and at the same time, what W.A. LaVallee calls "race traitor". Commenting on Jadine's disloyalty to her race, LaVallee 
points out that "The race traitor exists in willful ignorance of her native culture and racial/cultural identity." Willful, he says, "is important to this definition; mere ignorance of one's identity can be traced to upbringing or other factors, but to realize this and not wish to know is race traitorism". The pivotal conflict, however, is the conflict within Jadine. It is the cultural racial conflict of a woman who detaches self-identity from black identity. It is also the contention of a woman who has repudiated her heritage and black culture and embraced the traditional European culture. According to Rayson she "is ready to accept the life that Europe, here Paris, offers to a beautiful, well-educated black American woman" ().Like Pecola in Morrison's The Bluest Eyes, Jadine, according to Samuels and Hudson-Weems "is lost in a state of liminality. She is trapped between two cultures: black and white, European and African -American" (79).

As for Herbert William Rice, Jadine is “Morrison's first delineation of a young, modern, and educated black woman. She possesses all the pecuniary qualities of white society" and that the choices she makes "reflect her orientation toward bourgeois culture" (101).

Jadine is courted by a white European who represents wealth, position, power, and asexuality and by a black American with his poverty, anti-intellectualism, and sexuality. She, as Morrison writes, has learnt to like "Ave Maria' better than gospel music" and "Picasso . . . better than Itumba mask". (74) She is portrayed as an attractive young girl who is liberated yet vulnerable. She is endangered by the traditional roles of a woman that she does 
not want to get trapped by. Son wants her to "settle for wifely competence . . . to settle for fertility rather than originality, nurturing instead of building" (269). A role for women that culturally relates black women to their heritage, Barbara states that "The traditional black female activities of root working, herbal medicines, conjure and midwifery into the fabric of her stories to reveal the black women cultural experience.'(174) Itishri Sarangi states that, "Morrison intends to reconstruct the black image from her own experience. The richness of black culture includes black language, music, myth and rituals".

However, like Sula in Toni Morrison's Sula, Jadine rebels against the humble roles that black women often have in society. She thinks that the traditional roles expected of black women are too restrictive. She also believes that much of their time is devoted to "the domestic work of making life comfortable for others, resulting in a few chances for them to . . . realize their own self-fulfillment" as noted by Denard (173). Emancipated though Jadine is, her emancipation brings with it isolation from her ethnic heritage which is an important element of who she is. She has achieved a reasonable level of power and financial security; however, she uses it "either to anesthetize or distance" herself from her "black roots;" and, instead of making use of her "position to empower [her] race," she chooses to "ignore or scorn it" (Heinze 21-22). Her speculation on her betrothal to Ryk, her Parisian lover, displays her bewilderment about issues of race. She 
wonders whether Ryk is actually interested in marrying her or simply any other smart black girl:

"I wonder if the person he wants to marry is me or a black girl? And if it isn't me he wants, but any black girl who looks like me, talks and acts like me, what will happen when he finds out that I hate ear hoops, that I don't have to straighten my hair, that Mingus puts me to sleep ... ?" (48)

Disturbed by questions of race, Jadine is conscious that she feels unfaithful to her race at times, feels "a curious embarrassment in the picture of herself telling on a black man to a white man and then watching those red-necked gendarmes zoom him away in a boat"(126). So she longs for an identity segregated from colour. She feels uneasy with the way "Margaret stirred her into blackening up or universalizing out, always alluding to or ferreting out what she believed were racial characteristics" (64). Her endeavours to shun the allusion to her blackness nurtures the notion that Jadine believes in the superiority of the European white culture. "Sometimes," says Jadine, "I want to get out of my skin and be only the person inside-not American-not black-just me" (48). Ironically, Jadine is unable to perceive that 'just me' means that she is both American and black.

Brought up in a family dominated by white culture and educated in the Sorbonne, Jadine, as Heinze holds, "takes very little of her African roots with her into adulthood" (202). Morrison in The Bluest Eye states that: "I focused, therefore, on how something as grotesque as the demonization of an entire race could take root inside the 
most delicate member of society: a child; the most vulnerable member: a female" (170). As a child, Jadine's white patrons almost totally provide for her formal 'white' education. It is significant that she, unlike her aunt and uncle, is not a domestic sort of woman. Though Jadine helps Margaret with her secretarial work, she always dines with them and, like her white benefactors, is served by her aunt and uncle. She is therefore "a complete product of their program" (Samuels and Hudson-Weems 83) and "the construct of" their "white culture" (Rice 118).

What furthers the claim that Jadine is cultural racist is her obvious "racism to other black people" (LaVallee). Her racial attitudes manifest themselves in her interactions with other people, particularly the African woman in yellow, Son, the night-women, and her aunt and uncle. Early in the novel, for instance, "images of cultural differences," which "trigger a conscious sense of lack" and mark "Jadine's ambivalence toward black womanhood" appear in a vision (Bjork 115). In this vision, which Jadine recalls as she lies sleepless in her bedroom, Jadine is made to confront her "cultural heritage" when she accidentally meets, at a Paris grocery store, a tar-like African woman who "wears her heritage with pride and dignity" (Samuels and HudsonWeems 80). Jadine's encounter with this self-confident woman seems to be "a critical moment in her racial consciousness"(LaVallee), which reveals Jadine's inauthenticity as a result of denying her black heritage. It brings Jadine close to "her earth mother archetype" (Bjork 115). Before this crucial experience, Jadine "has perceived herself and is perceived to be white" (Heinze 22). The 
African woman, however, as Robert G. O'Meally notes, "mocks Jadine's successes . . . and haunts her dreams," and she seems to "personify something crucial and valuable about women and the black tradition" (36). She also "exhibits a cultural style that Jadine, as a race traitor, outsider, and cultural racist cannot adopt (LaVallee). In addition, the woman's "transcendent beauty" (46) has confounded Jadine and anybody else in the market:

The vision itself was a woman much too tall. Under her long canary yellow dress Jadine knew there was too much hip, too much bust. The agency would laugh her out of the lobby, so why was she and everybody else in the store transfixed? The height? The skin like tar against the canary yellow dress? The woman walked down the aisle as though her many-colored sandals were pressing gold tracks on the floor. . The people in the isles watched her without embarrassment, with full glances instead of sly ones. . . . Jadine turned her cart around and went back down the aisle telling herself she wanted to reexamine the vegetables. The woman leaned into the dairy section and opened a carton from which she selected three eggs. Then she put her right elbow into the palm of her left hand and held the eggs aloft between earlobe and shoulder. She looked up then and they saw something in her eyes so powerful it had burnt away the eyelashes.

She strolled along the isle, eggs on high, to the cashier, who tried to tell her that eggs were sold by the dozen or half-dozen - not one or two or three or four-but she had to look up into those eyes too beautiful for lashes to say it. She swallowed and was about to try again when the 
woman reached into the pocket of her yellow dress and put a ten-louis piece and walked away, away, gold tracking the floor and leaving them all behind. (45-46)

In 'The skin like tar, 'the canary yellow dress,' 'the white eggs,' 'the gold tracks' appears a band of colours that displays an "image of beauty capable of lifting people out of the corporeal into the spiritual" (Heinze 53). Jadine is perhaps aware that the woman seems to embody this image of beauty. Compared, however, with that incredible personality, Jadine feels dishonest and "knows herself to be . . . hollow" (Jokinen). She has made concessions while this African woman has not. In this woman, she discerns an essential blackness that she herself has subjugated in order to be successful in the white world of fashion. She "catches" in her "a glimpse of an essence, a beauty, an assurance, a womanliness, an indwelling elegance, a nurture, an authenticity that she had never known before" (Traylor 141). Unable to hide her admiration and even fear, Jadine follows the woman with her eyes. Unexpectedly, the African woman reacts to the sight of Jadine by turning her charming eyes on her and shooting "an arrow of saliva between her teeth down to the pavement"(46), expressing her disgust and condemning Jadine's inauthenticity.

Jadine experiences the awful look. At first, she responds to the woman's contemptuousness of her with heedlessness, but she soon feels unable to escape "the woman's insulting gesture," which has actually "derailed her" and "shaken her out of proportion"(47). Jadine has never understood the reason for the insult. For some reason 
she wants "that woman to like and respect her"(47).In contrast with Pecola, however, Jadine undergoes neither disgrace nor self-resentment; consequently, she is not wrecked by "the African woman's look"(Samuels and Hudson-Weems 81). Still, Jadine is made to "feel lonely in a way. Lonely and inauthentic"(46) by the woman's scornful look. Obviously, Morrison has depicted the fears and insecurities of a black woman in the modern world. Jadine has worked hard to be successful in what can still be seen as a white man's world. But her success as a model is subjected to suspicion by other blacks who think that Jadine has corrupted herself in the path to fame and success.

As Hinson noted, the restlessness and confusion Jadine experiences from this vision helps define "her status as a cultural self-exile" and strengthen her desire not only to "deny her own racial heritage" (177) but also to "resist any identification with the woman's maternal difference and, therefore, with her traditional cultural role" asserts Bjork(115). Jadine, however, does her utmost to "keep . . . the woman in yellow out of her mind" (49). For the remainder of the novel, she tries to get rid of that part of her which is also tar-like. Obviously, Jadine seems to reject anything that is likely to remind her of and associate her with her black roots. However, Jadine's encounter with the African woman functions as a painful reminder of how Jadine has become "a bauble for the indolent Western culture"( Heinze 39). Mean-time, It foreshadows the rest of her experiences with Son, the night-women, and her aunt and uncle. 
[4]Cultural Racism, history and the black heritage and Identity

Jadine's interactions with Son display the extreme differences in their cultures and reveal her disloyalty to her race. According to Heinze,

Jadine and Son are a sociological study of two different cultures - the sophisticated, accomplished Jadine epitomizing the best of white culture; the primitive, sensual Son, the best of black culture. In many ways, they, as a pair, represent the schizophrenia inherent in being black in a white America. She is the persona, the public mask struggling to gain acceptance and he is the soul, the anima keeping alive a culture threatened by extinction. That they cannot resolve their differences, indeed, that their relationship becomes violent, is a manifestation of the psychic fragmentation of the culture as a whole. (37)

Son is considered "a cultural tar baby" who, like cultural tar babies of folk tales, is "an active snare" (Hinson 190). As Trudier Harris explains, "we usually interpret Jadine and Son as tar babies. Both of them have some irresistible attraction ... that could potentially bring about their downfall" (qtd. in Hinson 190). However, when Son first sees Jadine, he is bewitched by her beauty but soon comes to realize "how that beauty has been commercialized in the slick pages of beauty magazines"(Heinze 38). As the embodiment of traditional African-American values that have been discarded, Son wants to show Jadine "the superficiality of her cosmopolitan values"(Smith 39). He attempts to save her from the inauthentic white world and 
bring her back to her genuine roots which she as well as her aunt and uncle have repressed. He wants to "breathe into her the smell of tar and its shiny consistency" (120). His strong liking of negro life manifests itself in his sheer desire to implant in Jadine his dream of

yellow houses with white doors which women opened and shouted Come on in, you honey you! And the fat black ladies in white dresses minding the pie table in the basement of the church and white wet sheets flapping on a line, and the sound of a six-string guitar plucked after supper while children scooped walnuts up off the ground and handed them to her.(119)

Alienated, however, from African-American culture and nurtured on white ways, Jadine turns a deaf ear to Son's values and repudiates the lifestyle of Son's hometown, Eloe. For her

Eloe was rotten and more boring than ever. A burnt-out place. There was no life there. Maybe a past but definitely no future and finally there was no interest. All that Southern small-town country romanticism was a lie, a joke, a secret kept by people who could not function elsewhere. (259)

She finds out that she is unable to deal with the black people of Eloe who fail to share her background: "She needed air . . . and conversation in a language she understood. She didn't want to have any more discussions in which the silences meant more than the words did" (259). What Jadine dislikes most about Eloe is its primitiveness and its people's uncivilized conviction that "sex is dirty or strange ... (257). In Eloe she finds 
her sexual freedom curtailed and feels obscene, because within the hierarchy of Eloe, the ancestral role of women as nurturers, as guardians of the hearth and moral values of the community, is also the preservation of male dominance. (Paquet 511)

Jadine's rejection of whatever Eloe represents is, in actuality, a rejection of her black roots. This brings about irresolvable conflict with Son, who is "a bearer of traditions" and "Tar Baby-like" (O'Meally 36). Unlike Jadine, Son cherishes the black world and rises above the pleasure and security which she finds in the white world. For him, blackness is not merely a color; rather, it is "a cultural identity inextricably tied to social stratification and marginalization" (LaVallee). When Jadine attempts to change Son to the better, get him into college, and secure a job for him so that they can live together on her own terms, Son refuses to get educated and scolds her "for acting and thinking white, for being the tar baby made by the white man to trap the black man"(Rayson). Presenting sharp contrast to Jadine's racial tendencies, Son sees "Jadine as an unthinking tool of the white world" (Werner 162). Sharing in the Streets' high-living, Son is emotionally racked by pain, particularly when he watches Yardman (a black man whose real name is Gideon, employed by Valerian) performing a detestable hard work (LaVallee), while he himself is strikingly clean:

But now watching Yardman-he was kneeling, chopping at the trunk of a small tree-while he himself was so spanking clean, clean from the roots of his hair to the 
crevices between his toes, having watched his personal dirt swirl down a drain, while he himself stood wrapped waistto-thigh in an Easter white towel-now he was as near to crying as he'd been since he' $d$ fled from home. (140)

Obviously, Son, unlike Jadine, is sympathetic with and loyal to his black folk. Nevertheless, Jadine's first encounter with Son testifies to her lack of "awareness and selfknowledge" (Rice 113). When Son goes unnoticed into Jadine's bedroom, she is abruptly "transfixed by his image that she envisions in the mirror" (Bjork 122). She, as Werner notes, "recognizes Son as a tar baby, a threat to her safety"(163).As she looks in the mirror, she sees "animallike qualities in him"(Rice 112). First, she is repelled by his smell. Then she perceives his "overpowering-physically overpowering" hair (113). Jadine speculates upon it as "long whips or lashes that could grab her and beat her to jelly"(113). Later she regards it as "wild, aggressive, vicious hair"(113). However, she struggles "to pull herself away from his image in the mirror;" once she thinks she is "freed at last," she turns to the actual presence of Son in her bedroom, but sees only "the riverbed darkness of his face"(114). Ironically, while Jadine perceives the uncivilized in Son, she fails to see and is "almost completely unaware of the same qualities in herself" (Rice 112).

Morrison describes Son's attraction and the effect it has on Jadine as "small dark dogs galloping on silver feet" (113), whose "lashes" Jadine is constantly "searching for"(115). In Son's presence, Jadine strenuously endeavors 
to curb the dogs because, according to Rice, Son "attracts her" (113). Jadine, in this scene, experiences not only "Attraction" but also "repulsion, eruption and repression" which "all merge into her mirrored creation"(Bjork 122-23). She undergoes a sort of difficulty to liberate herself from the image because its outburst echoes her desire for that 'wild, aggressive, vicious' difference which she has suppressed and which she now consciously displays on meeting Son. Bjork notes, "from the interstices of Jadine's consciousness" proceeds "a nebulous, imaged self that perpetuates her attraction to that which she is not"(123). Basic to this scene, however, are the mirror and the coat. Dressed in a black and white sealskin coat offered by her Parisian lover, Jadine looks at herself in a full-length mirror. She sees Son's horrible "chain-gang hair" (113), but she fails to perceive the savagery which her coat represents. It is made from "the skins of ninety baby seals, each of which was brutally killed" (Rice 113). Obviously, Jadine's coat stands for the power and savagery of European civilization, since it is a product of bourgeois culture, not African culture. Shani Adia Evans in her review of Candice M. Jenkins' book, Black bourgeois: class \& sex in the flesh, comments on the fact that, "there are many examples of wealthy blacks being subjected to racist treatment, it is not Jenkins's goal to discern whether class privilege reliably protects black bodies. Rather, it is the persistent belief that class privilege should protect that creates the "ontological tension" in Black Bourgeois". (478)

Ironically, Jadine, as Rice notes, "does not see such savagery in herself; she sees it in Son"(113). If this indicates 
anything, it indicates Jadine's estrangement from black culture and black identity in which she is unconsciously moulded and her belief in the superiority of European culture. It is worth mentioning that Jadine's interactions with Son unmask her enshrouded contradictions and "bring the race traitor to full profundity" (LaVallee). The exchange between Jadine and Margaret about Son is significant. Margaret informs Jadine of her displeasure with Son's stay with them in the same villa. When Margaret fails to find a word to refer to Son, it is, ironically, Jadine who "supplies the hesitant Margaret with the 'appropriate' vernacular" (LaVallee), not realizing that she shares Son the same colour:

"I'm going to have it out with Valerian. He's doing this just to ruin Christmas for me. ... Instead of throwing that . . . that ..."

\section{"Nigger."}

"Right, nigger, instead of throwing him right out of here." (129)

Jadine "had volunteered nigger" (129), a word, as Rice notes, "that codes color with savagery" (112). Ironically, however, Jadine forgets that she is black and a descendant of blacks, that blackness is a genuine feature of the very ethnic group she endeavours to isolate herself from. If blackness means savagery, then Jadine is savage. In a like manner, Jadine's alienation from her roots is evident when Son discloses his jealousy of what he views as "a conflict between Jadine's loyalty to him and her loyalty to her white . . . benefactors"(Samuels and Hudson-Weems 85). He 
accuses her of cultural racism, of revealing prejudicial attitudes toward blacks in favour of whites: "You . . . turn your black brothers into white brothers; you turn your men into white men and when a black woman treats me like what I am . . . you say she's spoiling me" (270).

Not only does Jadine feel prejudice toward her black folk, but she also depreciates them as well as her past, seeing it as "a medieval black slave basket" (270). She thinks they'd better remain oblivious to their past, a further evidence of her desire to keep away from her roots:

"There is nothing any of us can do about the past but make our lives better, that's all I've been trying to help you do. That is the only revenge, for us to get over. Way over. But no, you want to talk about white babies; you don't know how to forget the past and do better." (271)

Barbara Hill Rigney, however, sees that Jadine is wrong about her claim that 'There is nothing any of us can do about the past.' She thinks that Son's final retreat to the swamp in order to seek the legendary horsemen is a retreat to a mythic past which paradoxically both frees and destroys him. She also holds that Jadine "is equally trapped in a present constituted of false realities" because of being "excluded from myth and folklore by her white-world connections"(80).

In her first serious exchange with Son, Jadine manifests an ability to think of the blacks in a stereotypical way. The confrontation is significant since it exhibits "the confusion that forms the crux of her personal conflict" (Samuels and Hudson-Weems 81). On seeing Son, Jadine, 
like her white benefactors, thinks that Son is only capable of "rape, theft, or murder" (91). She lets him know about her initial reaction by admitting that she does not figure out what he "want[s] from us" (118). When Son wonders about Jadine's inability to distinguish herself from the Streets, she points out, "I belong to me. But I live here. I work for Margaret Street. She and Valerian are my ... patrons. ... They educated me. Paid for my travel, my lodgings, my clothes, my schools" (118). Significantly, her reaction reveals the contradictions underlying her life: on the one hand, fulfilling cultural independence is what occupies her most; she must not belong to anyone but herself. On the other hand, by living under the patronage of the Streets she "has inevitably grounded herself in their culture," which has eventually led to her "cultural confusion" (Samuels and Hudson-Weems 81-82).

As soon as the exchange between Jadine and Son grows in intensity, Jadine, thinking Son is about to rape her, reacts in terms of white culture, showing how her stereotypical attitude toward blacks is deeply fixed: "You rape me and they'll feed you to the alligators. Count on it, nigger. You good as dead right now" (121). Son's response is stereotypical, too. He accuses her of adopting the white conventional view of the African people: "Rape? Why you little white girls always think somebody's trying to rape you?'(121). When Jadine grumbles at being called 'white,' Son's reaction - "Then why don't you . . . stop acting like it" (121) - undoubtedly "ignores the content and focuses on her behaviour" (Peach 89). Enraged though she is by Son's imprudent description of her as white, Jadine fails to 
conceive what Son hints at and "continues relatively unchanged, mimicking the lifestyle of the rich WASP culture. She . . . then . . . establish [es] a standard that is adverse to community and conducive to bitter competition" ( Heinze 22-23).

Son sees Jadine's behaviour as an attempt on her part to "typify her adopted culture" (Samuels and HudsonWeems 82). Still, Jadine denies what her external behaviour indicates, claiming that she could not be defined externally by being told "what a black woman is or ought to be" (121). Obviously, Jadine is not merely reacting to having been recognized by a black man as "someone who has betrayed her race," but she is also responding to a black man who wants to "deny her right to think for herself" (Peach 89). However, instead of trying to give up part of her adopted white identity, she endeavours to define herself in terms of white culture:

"You can't, you ugly barefoot baboon! Just because you're black you think you can come in here and give me orders? Sydney was right. He should have shot you on the spot. But no. A white man thought you were a human being and should be treated like one. He's civilized and made the mistake of thinking you might be too. That's because he didn't smell you. But I did and I know you're an animal because I smell you." (121)

Clearly, Jadine embraces white culture, identifying it as important and superior to black one. This, ironically, testifies to her rejection of her black heritage. Though Jadine can 'smell' Son, she comes to realize that his body 
odor, which she associates with his black colour, is not so repellent as she thinks; she is, in fact, "attracted by it" (Samuels and Hudson-Weems 82). Son, Morrison writes,

"had jangled something in her that was so repulsive, so awful, and he had managed to make her feel that the thing that repelled her was not in him, but in her. That was why she was ashamed. He was the one who smelled. Rife, ripe. But she was the one he wanted to smell." (123)

Obviously, Jadine is 'ashamed' because she is not able to confront the unknown in herself. What Jadine finds disagreeable in Son is his raw blackness, manifested by his overpowering hair which he proudly wears to assert the African heritage to which he sticks firmly. Ironically, What she smells in him and is sure exists in her is, according to Samuels and Hudson-Weems, "their black heritage, which . . . she tries to deny with her non-committed definition of self" (82-83).

In a later encounter with Son, Jadine reveals her submissiveness to the white world. When Son expresses his abhorrence of white people in general and Valerian in particular, Jadine acutely defends Valerian, admitting that "He's a person, not a white man. He put me through school" (263). Son is amazed at Jadine's assertion of her indebtedness to Valerian. $\mathrm{He}$ is fully convinced that it is Valerian who owes Jadine as well as her aunt and uncle their services and devotion. According to Son, Valerian is indebted to them, not they to him:

"Why not educate you? You did what you were told, didn't you? Ondyne and Sydney were obedient, weren't 
they? White people love obedience-love it! Did he do anything hard for you? Did he give up anything important for you?" (263)

When Jadine fails to wake up to the appalling reality of whites, their exploitation of blacks, and the inadequacy of their education system that deliberately ignores black culture, Son voices his contempt for the white education system. He holds it responsible for Jadine's estrangement from her black culture:

"The truth is that whatever you learned in those colleges that didn't include me ain't shit. What did they teach you about me? What tests did they give? Did they tell you what I was like, did they tell you what was on my mind? Did they describe me to you? Did they tell you what was in my heart? If they didn't teach you that, then they didn't teach you nothing, because until you know about me, you don't know nothing about yourself. And you don't know anything, anything at all about your children and anything at all about your mama and your papa. You find out about me, you educated nitwit!'(264-65)

Son's aversion to the white education system exhibits his consciousness of and his affinity to his history, race and community (Campbell). According to Mbalia, Son "sees himself as a member of the exploited class" and "understands that if African people . . are exploited, then he too is exploited, that if African people are not free, then he is not free"(qtd. in Campbell). During a similar confrontation Son, again, expresses strong antagonism 
toward white people by rebuking Jadine for planning to marry a white man. He asserts that blacks and whites must not intermingle:

"You sweep me under the rug and your children will cut your throat. That fucker in Europe, the one you were thinking about marrying? Go have his children. That should suit you. Then you can do exactly what you bitches have always done: take care of white folks' children. Feed love and care for white people's children. That's what you were born for; that's what you have waited for all your life. So have that white man's baby, that's your job. You have been doing it for two hundred years, you can do it for two hundred more. There are no 'mixed' marriages. It just looks that way. People don't mix races; they abandon them or pick them. But I want to tell you something: if you have a white man's baby, you have chosen to be just another mammy only you are the real mammy 'cause you had it in your womb and you are still taking care of white folks' children.”(269-70)

To marry a white man is for Son the worst of race betrayals.

As the novel draws to its end, Son and Thérèse, a black woman who often comes to Valerian's villa and helps with the household burdens, are in a boat headed toward Isle des Chevaliers. She asks Son to seek his people, the blind, black descendants of slaves who were deserted on the island, instead of returning to Jadine:

"Hurry,"she urged him. "They are waiting."

"Waiting? Who's waiting?" Suddenly he was alarmed. 
"The men. The men are waiting for you." She was pulling the oars now, moving out. "You can choose now. You can get free of her. They are waiting in the hills for you. They are naked and they are blind too. I have seen them; their eyes have no color in them. . . . Go there. Choose them."(306)

According to Thérèse, Jadine has nothing to give him as she "has lost her ancient properties"(305). It is almost as though she were asking Son to make a choice between Jadine and the horsemen. As Samuels and Hudson-Weems note, "things do not resolve themselves in Jadine's and Son's favour"'(92). Both Son and Jadine cannot reject their upbringing, their cultural and geographical differences, and their racial attitudes. Jadine is unable to get accustomed to the simple life of black people on account of her addiction to the white world, and Son finds it impossible to become a middle-class black assimilating "Western definitions of value and meaning" (Heinze 37). The race traitor, as Samuels and Hudson-Weems note, fails to "resolve the cultural conflict and her personal fragmentation" (92), as a result of succumbing to white culture and willfully discarding her ethnic heritage which is part and parcel of her. Manivannan R. in her White Skin is an obstacle and Search for Love in Toni Morrison's Tar Baby, elucidates that "Jadine and Son's key characteristics are so different, but they are all vitally important. . . Jadine is a black materialistic, oblivious to her background and its blackness. Son is a black man who has strong links to his history and 
blackness... Son has a history, Jadine has a future, and everybody has a language".

A reminder of the importance of one's roots in maintaining one's cultural identity in the face of other dominant cultures is Jadine's interaction with the night women - several women from Eloe, Rosa, Thérèse, Son's dead mother, Aunt Ondine, Jadine's own dead mother, and the African woman from Paris. It reveals her cultural orphanage and helps bring "Jadine into close contact with the 'traditionalism' that by implication she has rejected" (Hinson 195). In this regard, Jadine, according to Shawn Peterson, is reminiscent of Sethe in Morrison's Beloved whose "isolation from ancestral community . . . makes her yet another of Morrison's 'cultural orphans' (191). When Jadine returns to Eloe with Son, they decide to spend a couple of days at Son's Aunt Rosa's home. While there, Jadine's moral awareness is aroused when Aunt Rosa sees her naked in bed and offers her a nightgown. Jadine, not feeling ashamed or guilty, does not turn her offer down. Shortly afterwards, when Son falls asleep, a group of women "make a visitation" (Samuels and Hudson-Weems 90 ). Jadine's past and present enter through a dream:

Rosa and Thérèse and Son's dead mother and Sally Sarah Sadie Brown and Ondine and Soldier's wife Ellen and Francine from the mental institution and her own dead mother and even the woman in yellow. All there crowding into the room. Some of them she did not know, recognize, but they were all there spoiling her love-making, taking away her sex like succubi, but not his. (258) 
The women Jadine confronts in this dream seem to be the women of her past and present, including her own biological mother, her surrogate mother, and all the women of Eloe. They appear to represent "traditional black womanhood, if not motherhood, which Jadine denies and from which she is running away" (Peach 86). The tenacity and abhorrence of the ghost women she encounters not only express Jadine's inner conflicts to liberate herself from African cultural heritage, but they also reveal Jadine's dilemma as an orphan, her feeling of having lost her mother, and perhaps her feeling of commitment to her adoptive parents. To Jadine the world the night-women represent is an archaic world which does not allow any notions of independence for women. Submitting to Son and the ghost women would mean settling for the traditional maternal role underlying black culture. The ghost mothers are Jadine's tar babies who, according to Hinson, "are the sticky black past in which she could become mired if she isn't careful, just as Son was her tar baby - she would have to wash him off, stinging and stinking, with gasoline" (196). In a like manner, "the African 'woman in yellow'. . . is really, with her 'skin like tar,' a tar baby to Jadine, a dazzling temptation, but actually a trap, an illusion, not a valid object of desire or emulation" (qtd. in Hinson 196). Jadin's renunciation of the ghost women and their world is, however, a renunciation in part of her roots.

Jadine, however, responds to the night women with horror and feeling of guilt. She thinks the night-women are denouncing her for having discarded "the traditional, maternal role in favour of material, success-oriented 
ambitions"(Bjork 136). They seem to Jadine "somehow in agreement with each other about her, and [are] all out to get her, tie her, bind her. Grab the person she works hard to become and choke it off with their soft loose tits" (262). Unable to put up with her panic, "she got mad and sat up," screaming, "What do you want with me goddamn it!"( 258). Jadine shuns confrontation on account of her feeling “inferior to these 'night women'(Smith 39) and her inability to "reconcile the fragmentation she feels as a member of an ethnic group for which she feels no affinity and a product of culture that finds no value in her ethnicity"(Heinze 253).

Nonetheless, the night-women seek to implicitly alert Jadine to the possibility of infertility that might result from rejection of black womanhood. So, in order to make Jadine understand the significance of "femaleness, fertility and motherhood" (Peach 87), each woman "pulled out a breast and showed it to her. Jadine started to tremble. They stood around in the room . . . revealing one breast and then two and Jadine was shocked" (258). Meanwhile, the woman in yellow "did something more shocking - she stretched out a long arm and showed Jadine her three big eggs" (258-59), further symbols of fertility and motherhood. Showing momentary attraction to the image of fertility, Jadine responds, "I have breasts, too" (258). But eventually, she is disappointed when she feels that "they didn't believe her" as "they just held ... their own [breasts] higher and pushed their own farther out and looked at her" (258).

The use of breast image calls forth the notion of the mother or nurturer. In a broader sense, the woman is the sustainer of her people, the culture-bearer of her race. In this 
concern, the night- women, like the African woman and Son, are Jadine's cultural tar babies who attempt to foster in her a healthy inclination to her black culture and heritage. Jadine is offered two chances so as to be saved from her lack of awareness, and in both instances her saviors are women. The first chance is given by the African woman in yellow while the second one by the night- women:

In both instances, Jadine rejects their services as culture bearers. In the case of the former, Jadine, once her consciousness is challenged, flees from her 'adopted' culture (Paris). With regard to the latter, she, challenged while immersed in the black culture in Eloe, later flees back to the adopted culture (Paris). Hence her flight reflects a futile cycle. (Samuels and Hudson-Weems 91)

Although Jadine fails to recognize it, the nightwomen exhibit a positive force. Since they personify Jadine's "ancestral mothers," they intervene in her life to remind her of her "culturally specific moral obligations" (Peach 86-87). Like the communities of women in The Bluest Eye, they are keen on liberating Jadine from that negative unconscious part of her identity. According to Samuels and Hudson-Weems, "these women can be said to be interested in healing Jadine of her inauthenticity, trying to restore the ancient properties she has lost as a result of losing contact with her culture"(91). However, Jadine renounces the ancient properties of African people that the African woman in yellow, Son, and the night-women incarnate. Afraid of "being cast as a representative of her race and joining its "fraternity," Jadine keeps her constant 
loyalty to the white world, thinking, ironically, that "to return to one's 'roots' has the psychic resonance of returning to a subjugated position"(qtd. in Jokinen). Deplorably, Jadine has chosen to abandon her black culture and become a protégé of the dominant culture.

In a sense, Sydney and Ondine are, like their niece, a product of white culture. They have served Valerian for almost thirty years when they are first introduced to the reader. "In that time they have become dependent upon Valerian for the very air they breathe" (Campbell). They associate themselves more with their white masters than they do with their own folk (Campbell).

Their reaction to Son upon finding him in Margaret's closet is typically white. Like Margaret who has a spite against Son for hiding in her closet, Sydney and Ondine, surprisingly, feel prejudice toward him instead of sympathizing with him. Sydney, "the epitome of the faithful retainer - the much-wished-for reliable black (McKay 6), has a gun to "ferret out the intruder"(144). He looks down upon Son as "a wife-rapper (99), "a . . . stinking ignorant swamp nigger," or "a wild-eyed pervert who hides in women's closets (100). His "superiority complex"(Campbell) manifests itself when he speaks with Son, making him feel that his origin is genuine and superior to Son's:

"I know you, but you don't know me. I am a Plil-adelphia Negro mentioned in the book of the very same name. My people owned drugstores and taught school while 
yours were still cutting their faces open so as to be able to tell one of you from the other."(163)

Obviously, "Sydney's words cut to the bone with racism. He has chosen to identify with his oppressors rather than the oppressed" (Campbell). Ondine, too, is suspicious of Son, calling him "that jailbird" (190) and "a swamp nigger" (191). She also hopes that "Mr. Street . . w would get rid of that thieving Negro" (89). In addition, Sydney and Ondine feel superior to the local black populace. "Part of this feeling of superiority might be class-related" (Jokinen). They boast of their positions in their white master's villa since they are "industrious"(61) and devoted to the Streets. Feeling they are "the proudest people in the race" (61), they regard the other black servants in the villa as "depersonalized figures" (Jokinen). This is evident in their indifference to their assistants' names - they nickname Gideon and Thérèse "Yardman" and "Mary (40). Sydney sees himself and Ondine as having transcended performing menial tasks which servants like Thérèse and Gideon are accustomed to. "Well, what you don't have the strength for, Yardman is supposed to do. I don't want you running all over the yard after chickens. . . We long past that," Sydney said, addressing Ondine (98). However, If Sydney and Ondine call themselves 'Phil-a-delphia Negroes' and view themselves as "a cut above their slovenly brethren," they are, in actuality, "cut off from any community" (qtd. in Hinson 184) and segregated from their own cultural roots. If racial prejudices exist between the black people of the house, it is not surprising that their white masters should 
show racial tendencies toward them. Although Margaret, the prejudiced white lady of the house, thinks that "Ondine (if not all colored people) was just as good as they were, she didn't believe it" (59). When she discovers Son in her closet, her fear drives her frantic. The one word that she can use is "black" (79). She thinks that he wants to rape her, has masturbated on "her French jeans or . . . her Ann Klein shoes" (86). She does not hesitate to call or look upon him as "a nigger in the woodpile" (83), or "a gorilla" (129), thus spitting "every racist cliché in the book" (Jokinen).

Ondine and Sydney work hard to please their employers to the extent of giving Jadine over to Valerian and Margaret, who guide her choices and mold her ways and steer her thinking . . ." (Traylor 140). Ironically, however, by entrusting Jadine's upbringing and education to white people, Sydney and Ondine partake of culturally orphaning their niece. The reason is simply that Valerian and Margaret cannot be model parents to Jadine since they fail to be ideal father and mother to their own son, Michael, who has been abused and tortured by his mother. Still, by sending Jadine to Europe to receive her education, the Streets seek to expose her to the foreign culture which is supposed to influence "the young child at her most transitional and impressionable years" (Samuels and Hudson-Weems 83). Jadine, on the one hand, is thus made to be moulded by white culture. She, on the other hand, has "very little exposure to an African or African-American heritage or values"(Hinson 191). It is no wonder then that she simultaneously assimilates the distorted values offered her by white institutions and rejects the genuine values 
presented by black culture. If Jadine acts like a white girl, then it is due to the fact that she has been brought up on white culture and detached from her black heritage. If her aunt and uncle encourage her estrangement from her black roots, Jadine, however, is partly responsible for "the actual maze that has bound her" (Samuels and Hudson-Weems (83). She, according to Linden Peach, is to blame for "her commitment to her own individual fulfillment rather than to a sense of solidarity with other black people" (90). Jadine's haughty attitude toward blacks is seen by Mbalia as "inhuman" and "a trap" set by "the European . . . for other Africans, an artificial lure to tempt them to a Europeanized lifestyle" (qtd. in Peach 83). Itishri Sarangi refers to Morrison's attempts to encounter cultural racism, "by creating a consciousness in strengthening the values of black cultural heritage through literary representation where blacks were denied of equality and freedom by the white American culture".

Jadine's ungrateful reaction to the benevolence of her aged aunt and uncle elicits her betrayal of the norms and values common to and shared by African-American people. Although Sydney and Ondine have contributed much to Jadine's education, she breaks with them in order to join her Parisian lover. She leaves them to "work out their own problems despite the fact that they are in need for financial help if they are ever to break with Valerian" (Rice 120). However, before Jadine leaves for Paris, her aunt attempts to teach her one of the ideals dictated by black culture: one's dedication to his or her family and older people in 
particular. She tells her that a girl can become a good woman if she first learns to be a good daughter:

"Jadine, a girl has got to be a daughter first. She have to learn that. And if she never learns how to be a daughter, she can't never learn how to be a woman. I mean a real woman: a woman good enough for a child; good enough for a man-good enough even for the respect of other women. Now you didn't have a mother long enough to learn much about it and I thought I was doing right by sending you to all them schools and so I never told you it and I should have. You don't need your own natural mother to be a daughter. All you need is to feel a certain way, a certain careful way about people older than you are. Don't mistake me now. I don't mean you have to love all kinds of mean old people, and if it's in your mind that I' $m$ begging you for something, get it out. I ain't." (281)

Jadine misunderstands, thinking that her aunt seeks parenting. She considers her aunt's "idea of womanness . . . too restricting"'(O'Meally 35) or "a burden on her lifestyle"( Heinze 203). Lacking any sense of family and community, she responds ungratefully by refusing to care for her surrogate parents after they have devoted themselves to her education. "You," said Jadine, "are asking me to parent you. Please don't. I can't do that now" (281). It seems that Sydney and Ondine "have succeeded in creating a successful and self-sufficient woman, but not a daughter, not a caring, empathetic, generous woman"(Rayson). However, in order to clear up Jadine's misunderstanding, 
Ondine explains that a daughter cannot be a complete woman unless she learns to take care of elders:

"I am not asking you that. I'm just saying what a daughter is. A daughter is a woman that cares about where she come from and takes care of them that care of her. No, I don't want you to be what you call a parent. Not me, and not Sydney either. What I want from you is what I want for you. I don't want you to care about me for my sake. I want you to care about me for yours." (281)

Looking after elderly people is one of the issues that preoccupies Toni Morrison, who holds the notion of neighborhood to be a characteristic feature of black community:

And there was this life-giving, very, very strong sustenance that people got from the neighbourhood.... And legal responsibilities, all the responsibilities of that agencies now have, were people were taken care of, or locked up or whatever. If they were sick, other people took care of them; if they needed something to eat, other people took care of them; if they were old, other people took care of them. ( qtd. in Hinson 197 )

"To abandon her adoptive parents," as Hinson argues, "is to violate one of the basic precepts of the value system within the African-American community" (197). Obviously, this is perhaps one of the most unpardonable crimes Jadine has committed. Significantly, the term tar baby in this novel is ambivalent. In addition to the above meanings which it implies, it means for Morrison "the black woman who can 
hold things together" (qtd. in Jokinen). For Dorothy Lee, it suggests "black identity in a more general sense"(qtd. in Rice 116). It also "symbolizes the blackness that Jadine lacks"(Rice 117). Mark Riechers in 2019 considers Morrison as "a singular presence in American literature - a towering figure who probed and examined how ideas of whiteness and blackness shaped our culture".

Jadine's confrontations with the representatives of her ethnic past - the African woman who spits at her, the nightwomen of her dreams who taunt her with her incapability of motherhood, and her aunt who expresses her disapproval of her lack of concern for her family - are meant to caution Jadine (and her likes) not to lose connections to the values and traditions of the black women of her past. Black women, according to Morrison, have been capable of building the houses, bringing up the children, and not allowing education to preclude them from doing their duties as mothers. For black women to ignore their ancient qualities or to belittle their value "would be to diminish (themselves) unnecessarily"(qtd. in Denard 175). Itishri Sarangi praises Morrison for promoting Black culture in her works and for establishing a distinguished status for Blacks in American Literature".

[5]Throughout her novel Tar Baby, Morrison depicted the failure of the theory of cultural racism in creating a united nation. Morrison calls attention to the magnitude of one's ethnicity and cultural heritage in preserving one's cultural identity from other dominant cultures. The superiority when resorting to 'history' is not confined to European race or the 
West, African Americans have their own 'history' that participated in the creation of US. "Reconstruct(ing) African-American values, traditions and belief in order to show the importance of community to the development of self and place" is what Sebin Justine describes as Morrison's achievement within each of her novels and in Tar Baby.She introduced the solution for both racism and cultural racism: minorities keep their identity, culture, heritage and history within a framework of a society that respects 'the other', that sees no colour but the human being with the purity of heart and good intention towards all other humans. Her revelation is that America's lifestyle and its system of education are mostly responsible for the destruction of the African-American individuals, separating those who identify with white masters from those who identify with African-American people. The message she wants to convey is that African-American people must neither estrange themselves from their ethnic community nor deny their cultural heritage. Isolation from AfricanAmerican roots means the eradication of African- American identity. Morrison's Tar Baby succeeded in enlightening African Americans of the significance of conservation of their heritage and reconciliation of their own culture with the white national American culture. 
Works Cited

Angelo, Bonnie. Toni Morrison: The Pain of Being Black. Time, Monday, May 22, 1989

http://content.time.com/time/subscriber/article/0,33009 ,957724-5,00.html

Balibar, Étienne (1991). Is there a Neo-Racism? In Étienne Balibar; Immanuel Wallerstein (eds.). Race, Nation, Class: Ambiguous Identities. $\quad$ London: Verso. pp. 17-28. ISBN 978$\underline{0860915423}$

Bjork, Patrick Byrce. The Novels of Toni Morrison :The Search for

Self and Place Within the Community. New York:Peter Lang, 1992.

Blaut, James M. 1992. The Theory of Cultural Racism. Antipode: A Radical Journal of Geography, Volume 23 (1992) [Pages 289-299]

http://www.columbia.edu/ Inp3/mydocs/Blaut/racism. $\underline{\mathrm{htm}}$

Campbell, Sean. " Struggling with a History of Capitalism in Toni Morrison's Tar Baby."

U of Idaho. 22 July 2001 WWW.

its.uidaho.edu/banks/1999/articles/struggling_with_a_histor $\mathrm{y}$. 
Cecilia Barbieri \& Martha K. Ferede. A future we can all live with: How education can

address and eradicate racism. The Futures of Education Ideas LAB, 29 June 2020

https://en.unesco.org/futuresofeducation/ideaslab/barbieri-ferede-educationeradicate

Christensen, Lauren. Every Work of American Literature Is About Race': Writers on How

We Got Here. New York Times. June 30, 2020 https://www.nytimes.com/article/books-race$\underline{\text { america.html }}$

Chua, Peter (2017). "Cultural racism". The WileyBlackwell Encyclopedia of Social Theory.

Hoboken:

Wiley-

Blackwell. ISBN 9781118430866

Denard, Carolyn. "The Convergence of Feminism and Ethnicity in the Fiction of Toni

Morrison." Critical Essays on Toni Morrison. Ed. Nellie Y. McKay. Boston: G.K. Hall, 1988.

Edmunds, Susan. Houses of Contention:Tar Baby and Essence. American Literature 1

September 2018; 90 (3): 613-641. SEPTEMBER 012018

doi: https://doi.org/10.1215/00029831-6994829

https://read.dukeupress.edu/american-literature/articleabstract/90/3/613/135311

Engel, Valery. 2019. Can Europe Make it? Modern Racism. 26 April 2019 
https://www.opendemocracy.net/en/can-europe-

make-it/modern-racism/

Fox, Margalit. Toni Morrison, Towering Novelist of the Black Experience, Dies at 88. New

York Times. Aug. 6, 2019.

https://www.nytimes.com/2019/08/06/books/toni-morrisondead.

Heinze, Denise. The Dilemma of "Double Consciousness": Toni

Morrison's Novels. Diss. Duke University, 1990. Ann Arbor :

UMI, 1990. 9100098

Hinson, Douglas Scot. Reading the Blood : Violence, Sacrifice, and

Narrative Strategy in the Novels of Toni Morrison. Diss. The

Ohio State University, 1993. Ann Arbor: UMI, 1993. 9316166

Jokinen, Anniina. "The Inauthentic Tar Baby: An Essay on Toni

Morrison's Tar Baby." Luminarium. 1 July 2001 <www.lumi-

narim.org/contemporary/

tonimorrison/ taressay.htm. $<$

Jenkins, Candice M. Black bourgeois: class \& sex in the flesh. Minneapolis, Minnesota: University of Minnesota Press, 2019, p. 280. ISBN 978-1-5179-0580-4 
Justine Baillie, Introduction: Global Morrison, Contemporary Women's Writing, Volume 13, Issue 3, November 2019, Pages 253269, https://doi.org/10.1093/cww/vpaa008 https://academic.oup.com/cww/articleabstract/13/3/253/5886614

Justine, Sebin. Toni Morrison's Novels: A Bird's Eye View. Writers Editors Critics. Sep2019, Vol. 9 Issue 2, p1624. 9 p.

Kanneh, Kadiatu. "Racism and Culture." Paragraph, vol. 16, no. 1, 1993, pp. 34-46. JSTOR, www.jstor.org/stable/43263389. Accessed 27 Jan. 2021

Kishanrao, Chakradev Dnyaneshwar. Portrayal of Racism and Gender Violence in Tony

Morrison's $\quad$ Fiction. 2019.

https://shodhgangotri.inflibnet.ac.in/handle/123456789/766

$\underline{0}$

LaVallee, Andrew W. Faces as Black as His But Smug Race Traitor in Morrison's

Tar Baby." 17 June 1998.

https://www.scribd.com/document/102639651/null

Manivannan R. White Skin in an obstacle and Search for Love in Toni Morrison's Tar Baby,

The International journal of analytical and experimental modal analysis. Volume XI,

Issue X, October/2019 ISSN NO: 0886-9367

McKay, Nellie Y., ed. Critical Essays on Toni Morrison. Boston : G.K. Hall, 1988. 
Michael Banton. Racism. The Willey Blackwel Encyclopedia of Race, Ethinicity and

Nationalism.

30 December 2015.

https://doi.org/10.1002/9781118663202.wberen539

https://onlinelibrary.wiley.com/doi/abs/10.1002/978111866 3202. wberen539

Morrison, Toni. Tar Baby. New York: Knopf, 1981.

Mukherjee, R., S. Banet-Weiser, and H. Gray, eds. Racism Post-Race. Durham, NC: Duke

Univ. Press. 2019

O'Meally, Robert G. “Tar Baby, She Don' Say Nothin." "Critical

Essays on Toni Morrison. Ed. Nellie Y. McKay. Boston: G.K.

Hall, 1988.

Paquet, Sandra Puchet. "The Ancestors as Foundation in Their

Eyes Were Watching God and Tar Baby." Callaloo 13 (1990):

499-515.

Peach, Linden. Toni Morrison: Modern Novelists. New York : St.

Martin's Press, 1995.

Peterson, Shawn. Loving Mothers and Lost Daughters: Archetypal 
Selected Novels

Images of Female Kinship Relatives in

of Toni Morrison. Diss. University of Oregon, 1993. Ann

Arbor: UMI, 1993. 9322035

Pettigrew, Thomas F. "Racism." Oxford Bibliographies. 24 November 2020. DOI:

10.1093/OBO/9780199756384-0162,

https://www.oxfordbibliographies.com/view/document/obo9780199756384/obo9780199756384-0162.xml

Rattansi, Ali (2007). Racism: A Very Short Introduction. Oxford: Oxford University

Press. ISBN 978-0-19-280590-4

DOI:10.1093/actrade/9780192805904.001.0001

Rayson, Ann. "Foreign Exotic or Domestic Drudge? The African

American Woman in Quick Sand and Tar Baby." Melus

Summer, 1998. 15 July 2001 http://findarticles.com.

Rice, Herbert William. Toni Morrison and the American Tradition:

Rhetorical Strategies in the Novels. Diss. University of Georgia,

1993. Ann Arbor: UMI, 1993. 9320712

Rigney, Barbara Hill. The Voices of Toni Morrison. Columbus: Ohio

State University Press, 1991. 
Samuels, Wilfred D., and Clenora Hudson-Weems. Toni Morrison.

Boston: Twayne Publishers, 1990.

Sarangi , Itishri. 2016.The Outburst of Racial discrimination" in the novels of Toni

Morrison. Researchgate Publications, August 3, 2016.

https://www.researchgate.net/publication/305807292

The Outburst_of_Racial_Discrimination in the novels_of

Toni Morrison

Shahrezaee, Mina Aghakhani and Ladani, Zahra Jannessari. 2014. Toni Morrison's

Beloved and The Bluest Eye: A Cultural Materialistic Approach. International

Letters of Social and Humanistic Sciences 6 ISSN: 2300-2697, Vol. 30, pp 17-23

doi:10.18052/www.scipress.com/ILSHS.30.17

2014 SciPress Ltd, Switzerland

https://www.scipress.com/ILSHS.30.17.pdf

Shani Adia Evans (2021) Book Review Black bourgeois: class \& sex in the flesh, Ethnic and

Racial

Studies, 44:3, 478-

480, DOI: $\underline{10.1080 / 01419870.2020 .1779951}$

https://www.tandfonline.com/doi/abs/10.1080/01419870.20 20.1779951

Siebers, Hans; Dennissen, Marjolein H. J. (2015). Is it Cultural Racism? Discursive 
Exclusion and Oppression of Migrants in the Netherlands. Current Sociology. 63 (3):

$$
470
$$

489. doi: $10.1177 / 0011392114552504$. S2CID 143774014.

https://www.researchgate.net/publication/305807292_The

Outburst of Racial Discrimination in the novels of Toni Morrison

Simona Rodat. "Cultural Racism: A Conceptual Framework". Revista de Științe Politice.

Journal of Political Sciences, Romania Issue: 54/2017. 54:129-140.

https://www.ceeol.com/search/articledetail id $=729471$

Smith, Valerie A. Remembering One's Ancient Properties. Critical Essays on Toni

Morrison. Ed. Nellie Y. McKay. Boston : G.K. Hall, 1988.

Taylor, Derrick Bryson. "George Floyd Protests: A Timeline". The New York Times. Archived

From the original on June 2, 2020. Retrieved June 2, 2020.

Toni Morrison: Read 10 of her most empowering quotes on gender, racism and love. Published: 07th August 2019. www.edexlive.com

Traylor, Eleanor W. "The Fabulous World of Toni Morrison : Tar Baby. Critical Essays on

Toni Morrison. Ed. Nellie Y. MacKay. Boston: G.K. Hall, 1988. 
Werner Craig H. "The Briar Patch as Modernist Myth: Morrison,

Barthes and Tar Baby As-Is.” Critical Essays on Toni Morrison.

Ed. Nellie Y. MacKay. Boston: G.K. Hall, 1988. 